\title{
Ethnic Conflict: Looking Inside Groups
}

\section{Sherrill Stroschein}

\author{
University College London \\ s.stroschein@ucl.ac.uk
}

March 2016

\begin{abstract}
This article sketches the premises of a relational orientation to understanding ethnic conflict. Following on the work of Charles Tilly and others, it prioritizes relations and interactions in the dynamics of ethnic boundary preservation, rather than individual entities. I first outline the role of boundary activation mechanisms in ethnic conflict. I then present the interactions between elites and masses of ethnic groups in mixed settings that preserve coexistence, noting how a rupture of these interactions can lead to conflict. The aim of this orientation is to identify causal mechanisms and sequences in political processes. These mechanisms and sequences then serve as general statements that can be examined across a variety of settings. I conclude with a sketch of how progress in the field will involve a stronger focus on local research. In particular, the revered ethnic and political demographics of ethnic enclaves are a fruitful area for future research.
\end{abstract}


This piece emerges out of research on ethnic politics in Eastern Europe, and teaching on governance in divided societies generally. My research has emphasized politics in ethnically-mixed settings in which ethnicity is a salient part of politics. I am especially interested in places that have political conflict and not continual violence, but where there is the potential for violence and occasional incidents of mobilization to violence. I have approached empirics through a variety of ways: the use of local newspaper archives and event and sequence analysis, as well as via extensive fieldwork and interviews with an ethnographic eye (Stroschein, 2012). As democratization and mobilization are processes that are ongoing, endogenous phenomena, I have used methods that can evaluate the nature of political processes. Explanation takes the form of identifying causal mechanisms and meaningful sequences in processes, producing general statements that can be examined for validity in other settings. This approach stands in contrast to attempts to identify variables that are causes and effects, as they are less useful for understanding processes (Pierson, 1993; McAdam, Tarrow, \& Tilly, 2001; Beissinger, 2002; Stroschein, 2012, 2015). The relational approach in this piece reflects this orientation.

\section{What we know about the causal determinants of ethnic (or religious) conflict}

Ethnic conflict waxes and wanes over time, even within one setting. Its causes thus lie in interactive dynamics, rather than in static attributes or dispositions. A relational perspective, informed by work in sociology, focuses on ties and transactions between entities (Tilly, 2003, p. 8; Tilly, 2005, p. 28; Brubaker, 2002 p. 8). Relationalism stands in contrast to a perspective that prioritizes the interests and agency of individual actors (or groups understood as individual actors).

A relational understanding of ethnic or religious groups thus begins with interactions, rather than individual entities. From a relational perspective, group categories are a function of the creation and maintenance of a boundary, and it is this boundary that generates an understanding of groups (Barth, 1969). Figure 1 illustrates these dynamics. This diagram depicts an active boundary between categories $\mathrm{X}$ and $\mathrm{Y}$. $\mathrm{A}$ boundary is a zone of separation between clusters of population, ${ }^{1}$ demonstrated by a higher density of connections on each side of the boundary than across it (definition adapted from Tilly, 2005, p. 134). This difference in connections within and across a boundary is depicted in Figure 1 . On each side of the boundary, members of category $X$ and of category $Y$ maintain dense networks internally, but only sparse ties exist between members of $X$ and of $Y$. Ties within categories tend to include family and close friendship networks and are thus known as "strong" ties, while ties across categories more commonly take the form of acquaintance relationships, or "weak" ties. For general societal integration to be preserved in spite of categories, these "weak" cross-category ties play a crucial role (Granovetter, 1973).

\footnotetext{
${ }^{1}$ These are boundaries of practice, rather than geographic boundaries.
} 
Figure 1. Group Boundaries

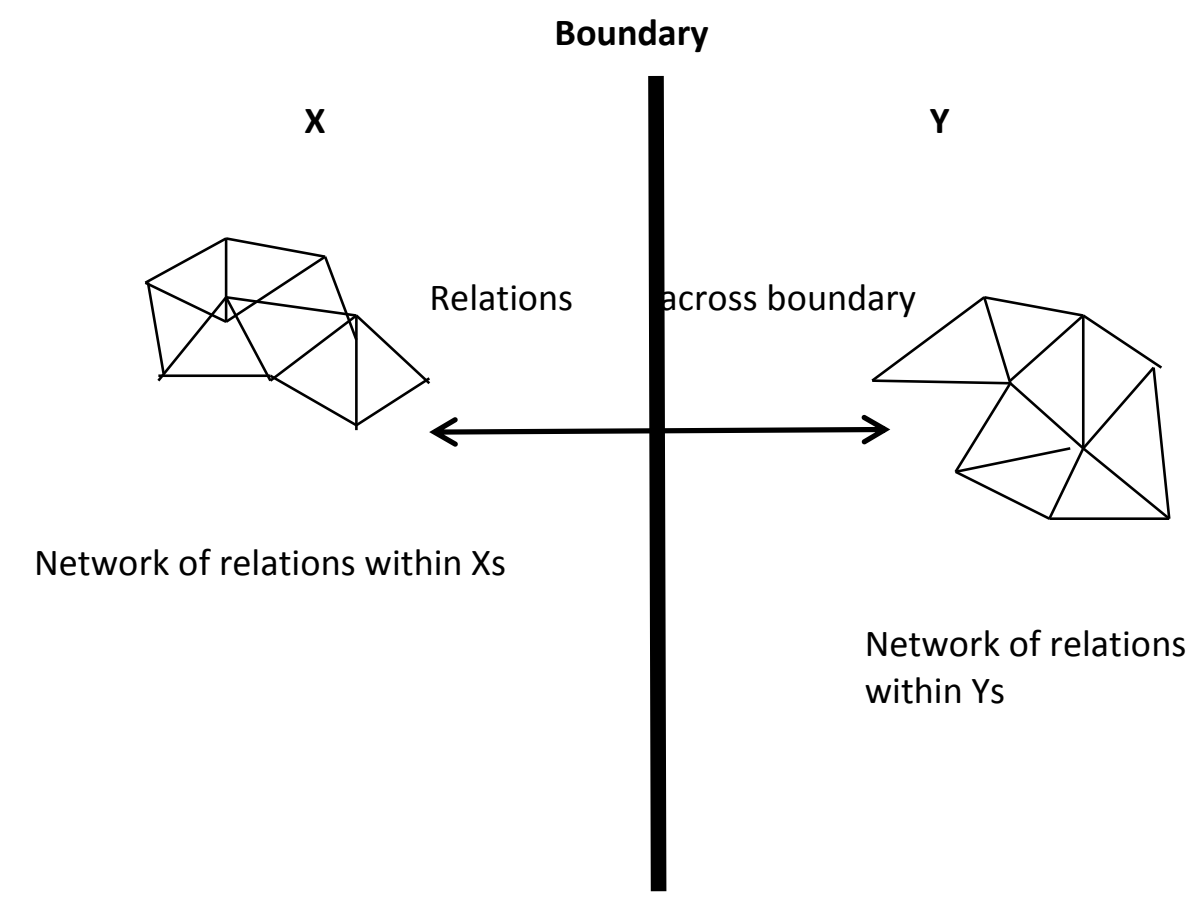

Figure 1: Group Boundaries. Adapted from Charles Tilly, Identities, Boundaries, and Social Ties (2005), p. 8.

In this understanding, ethnic or religious identities are "social arrangements." They involve 4 components: 1) a boundary, 2) relations within the boundary, 3) relations across the boundary, and 4) stories about the boundary and these relations (Tilly, 2003, p. 32; Tilly, 2005, p. 209; Kaufman, 2001). But boundaries are not stable entities. A boundary might weaken if a series of incremental practices over time might increase ties across the boundary and/or weaken the concentration of ties within each group. In addition, stories told about the boundary might begin to weaken its relevance in everyday practice. For example, if modernization processes might change the circumstances of those on each side of the boundary, new priorities such as an education or new employment prospects might weaken the boundary's significance. Conversely, boundaries might be latent but become reactivated under conditions of state breakdown, economic hardship, or uncertainty, as sense-making attempts might reactivate some of the older stories.

There has some good work done to establish the origins of the concept of ethnic identity in terms of the evolution of the meaning of these categories and their general usage (Horowitz, 1985; Connor, 1994; and Chandra, 2006, among others). However, the concept of boundaries can be applied across identity groups, including those with religious (Pearlman, 2014), ideological, economic, clan (Cunningham, 2009) or other distinctions that become politically salient. Mobilization can also involve an alignment of ethnic identities and economic identities (Hererra, 2004; Giuliano, 2011). One insight of boundary activation is that mobilization patterns take similar forms regardless of the content of the boundary in question (Tilly, 2005; McAdam, Tarrow, \& Tilly, 2001).

Mobilization processes originate in the activation of boundaries. The additional ingredient for mobilization is claim-making. Identity groups might make claims regarding their security, their rights, or perceived power hierarchies (Tilly, 2003 pp. 197, 238; Tilly, 2008 , p. 5). In addition, conditions of uncertainty in which the social ranking of groups is "ambiguous" can also produce claim-making as a contest for power (Tilly, 2005, p. 19). It is for this reason that the collapse of a state and its security structures, as took place in Iraq 
in 2003, might produce conditions that activate identity boundaries. In conditions of uncertainty, latent boundaries might provide one of the few available focal points. ${ }^{2}$ A power vacuum can also easily produce contests for power between these newly-activated identity groups, each making claims against the other.

Violence can be a strategy in these claim-making efforts. Violence is not a degree of conflict, but rather a form or a technique of interacting with the other (Brubaker, 2002, p. 91). Its alternatives include protests, strikes, and petitions. Prior violence often increases the probability that violent acts by other groups will follow, absent negotiated settlements. The source of violence also matters. State- or army-led violence that aligns with one identity group has a very different character from violent acts with local origins, such as a neighbor using the context of violent conflict to seek revenge (Roy, 1994; Ron, 2000; Gross, 2003).

\section{Most useful recent developments in the field of ethnic conflict}

Two main developments are worth particular note: 1 ) the relationship between individuals and collectives, and 2) group hierarchies under uncertainty.

First, what makes an individual act as part of a collective? In her work on Rwanda, Lee Ann Fujii (2008) found that some individuals have a high capacity to resist pressure to engage in ethnic killings ("resisters"), while others ("joiners") have a higher propensity to succumb to group pressure and participate in violence. This insight demonstrates that a combination of individual dispositions and relational dynamics lie behind ethnic conflicts. As noted by Brubaker, groups are projects with political goals (Brubaker, 2002, p. 13; Tilly, 2005, pp. 56-58). But even in successful groups with active boundaries, certain individuals might remain outside of these dynamics. A group is something that happens, more or less successfully - rather than a static entity (Brubaker, 2002, p. 12; Brubaker, Feischmidt, Fox, \& Grancea, 2006).

Research on mobilization has shed some light on how and when individuals begin to act as a group. Roger Petersen's work on mobilization (2001) outlines a model of individual propensities as well as interactive dynamics. He outlines a range of possible stances that individuals might take towards mobilization, ranging from least to most mobilized. Communities consist of individuals who are arrayed at varying points along the spectrum, with "fanatics and first actors" the most likely to act first (Petersen, 2001, pp. 9, 272). However, changes in community circumstances (triggering mechanisms) can move individuals across the spectrum, with those individuals who were previously latent becoming mobilized (Petersen, 2001, pp. 13-14). The "tipping" component in mobilization has also been noticed in revolutionary mobilization (Kuran, 1991).

More recent work by Petersen adds to this mobilization configuration (Petersen, 2011). Some join in mobilizations due to commitments stemming from emotion, close ties, group norms, or shared stories, while others may join due to coercion (Petersen, 2001; Tilly, 2005, pp. 56-58; Fujii, 2008). In addition, political entrepreneurs may actively coordinate mobilizations to serve political goals - and do so by brokering relations and framing stories that activate and sustain group boundaries (Tilly, 2003, p. 34). Some analysts have perceived these dynamics as an elite manipulation of conflict (Snyder, 2000), but the response of populations to elite appeals remains under-theorized without an understanding of group boundary activation (Brubaker, Feischmidt, Fox, \& Grancea, 2006). Elites can also play a crucial role in mitigating conflict (Fearon \& Laitin, 1996) or in negotiating resolutions to conflicts in the wake of even violent bilateral mobilizations

\footnotetext{
2 Some of the literature on civil wars also addresses how identities become more salient in uncertain conditions.
} 
(Stroschein, 2012). From this perspective, the successful negotiation of grievances and claims between groups in divided societies requires both a) ongoing negotiations between elites and b) brokerage between elites and "their" group masses. Brokerage requires that elites have resonance, or are viewed as legitimate spokespersons for the community would-be elites must draw a reciprocal response from their populations (Stroschein, 2012).

Second, how do group hierarchies operate in uncertainty? Rogers Brubaker defines ethnicity and ethnic conflict as "struggles for power between challengers and incumbents" that are "newly ethnicized, newly framed in ethnic terms." Power and struggles for power are the operative elements in ethnic or other identity conflicts - not ethnicity or identity itself (Brubaker, 2002, p. 90). It is through power struggles that large structural changes such state collapse are likely contexts for identity conflicts. With these disruptions, social relations are altered, and increased uncertainty increases the chance of violence (Tilly, 2003, pp. 225-30). Boundaries thus become more salient under conditions of uncertainty (Tilly, 2005, p. 51), with these contests over the new social ranking of groups. ${ }^{3}$ Unsettled claims regarding justice, power, and politics can lead to a turn to violence as a strategy (Petersen, 2001, pp. 34-35; Tilly, 2005, pp. 17-19, 51).

\section{Least useful recent developments in the literature on ethnic conflict: over time and recently and why?}

The application of mathematical approaches to large- $\mathrm{N}$ studies of conflicts can produce information on the mean, or average propensities, across a large sample of places. Useful predictive statements can originate from these large- $\mathrm{N}$ averages. But we might instead be interested in explaining the dynamics of a particular place. In post-1945 conflict databases, any particular place that is not average is simply an outlier. If we are interested specific dynamics, it is inappropriate to treat everything since 1945, or even 1991, as equivalent in both context and importance. A large- $N$ probabilistic analysis can be a first cut to consider where conflicts might be more likely, but it is less useful if we want to understand the dynamics of conflict on the ground as they unfold.

Another problem with much large- $\mathrm{N}$ research is that of inherent endogeneity. Statistical analysis generally prescribes that endogeneity should be "controlled for" using mathematical means. But endogeneity is at the heart of what is happening in processual dynamics - events at Time 1 drive the nature of events at Time 2 (Pierson, 1993; Abbott, 2001; Beissinger, 2002). An attempt to remove endogeneity from the analysis would mean that we miss the explanation. Moreover, events drive each other in ways that can vary by context, due to local specific dynamics. For example, a violent riot at Time 1 may lead to further violence at Time 2 , as identities solidify and polarize. However, those who experience or witness the violence at Time 1 may also make a conscious decision to avoid further such events at Time 2 (Stroschein, 2012). A relational and processual approach avoids these problems by prioritizing the dynamics of change in categories, as boundaries may shift from more to less active (Brubaker, 2002, pp. 18-19). Category attributes, used as variables in other types of analysis, are simply snapshots at particular points. A processual approach provides a means to examine the film as it unfolds over time.

Finally, there remains the sticky problem of agency. As noted by Almond \& Genco (1989), the production of law-like statements on social life assumes that it is appropriate to study society using the same scientific techniques applied to study non-humans - from

\footnotetext{
3 The mechanism of boundary strengthening under conditions of uncertainty differs from that rationalist accounts in which uncertainty relates to information amounts and signalling.
} 
physics and the hard sciences. But humans can be unpredictable, and learn and change over time. For this reason the social sciences are less amenable to the broad general statements of the hard sciences. How one approaches the units of study depends on an analyst's view of agency. As in the example above, learning and agentic decisions will influence the likelihood that a riot at Time 1 might affect the likelihood of riots at Time 2.

A relational approach handles generalization differently. Instead of producing broad covering laws, causal statements on general dynamics take the form of locating micro-causes in the form of mechanisms in processes. If these mechanisms recur, and if sequence patterns repeat, they are generalizable to other settings (Petersen, 2001; McAdam, Tarrow, \& Tilly 2001). The background science model here is one of biology, rather than physics. A mechanism such as enzyme production is generalizable across a variety of contexts and includes a sequence of events, but does not take the sweeping general form of a covering law. The existence of relations constrains actors, making it possible to observe general patterns in interactions over time and in different contexts. However, these constraints can still allow for innovation and agency (McAdam, Tarrow, \& Tilly 2001; Tilly, 2008). As mechanism approaches prioritize explanation over prediction, the search for causal mechanisms is often inductive. A detailed examination of empirics derives the mechanism and sequence statements, which can then be examined in other settings (Petersen, 2001, p. 12). Prediction requires faith that a general statement might travel across time and context to the future.

\section{What remains to be done to understand ethnic conflict?}

A next step in research on both violent and nonviolent ethnic conflict dynamics is to prioritize research on local politics. Much remains to be known about the degree to which generalizable patterns might be found in cities and towns with similar demographics, and the aspects on which they might differ (Stroschein, 2007). Varshney (2002) made some steps in this direction with his comparative study of Hindu-Muslim mixed cities in India, where he found that was not simply structural demographics but also cross-group networks that mattered for quiescence between groups. It is important to open up the state unit to see what is going on inside, at the local level.

A related avenue for local study relates to the politics of ethnic enclaves. Even before the descent of Yugoslavia into war, surveys of ethnic tolerance found interesting results in ethnic enclaves, or places where the state's ethnic minorities were local majorities. As reported by Massey, Hodson, \& Sekulić (1999), members of different ethnic groups showed high levels of intolerance when residing in enclaves, relative to their coethnics in other locations. Both the causes and the implications of the reversed ethnic dynamics in enclaves are important topics for study. We might posit that in democracies with decentralized local politics, the power reversals in enclaves might produce some of these effects of heightened intolerance. Or, it could be that enclaves in other locations are less intolerant, due to factors that are yet to be researched.

Enclaves also raise questions regarding local political party dynamics and their relationship to the central government. Research in Romania reveals that Hungarian enclave cities are not dominated in local politics by the main Hungarian political party. Instead, in enclaves there is splintering and outbidding, involving independent candidates and new parties (Birnir, 2007; Stroschein, 2011). This splintering dynamic has influenced the ability of the main Hungarian party to conduct politics at the central level (Birnir, 2007). My current research involves an examination of the interaction between local politics in enclaves and claims for increased autonomy for the enclave in the state.

The dynamics of local elections and municipal and county councils is important for understanding ethnic conflict for a variety of reasons. In democracies, power is transferred 
through elections, if this power transfer is routinized. Election violence takes place when there are disputes over this process. A transfer of power is always fraught with conflict of some kind. But in ethnic enclaves, we know from surveys that ethnic boundaries remain more salient than in other areas. Most of the time, this local majority-minority dynamic is settled in a local equilibrium of acquiescence by the local minority. However, the reversed ethnic dynamics of enclave settings make this equilibrium an unstable one. Romanians in the Hungarian enclave in Romania often chafe at the "lower" status of their language, culture, and representation there, and the central government sometimes makes a play for political support from Romanians across the state by intervening in the enclave on their behalf (Stroschein, 2012).

While such center-local interactions involving enclaves rarely make international news, they represent a persistent form of low-level conflict. Russian intervention into Crimea and Eastern Ukraine left media and other observers without words to describe the situation on the ground, because they lacked a framework to think about enclave politics. With an understanding of reversed demography and boundary activation, we have more conceptual tools to explain the interaction between the different elements in such an unfolding conflict.

Fieldwork for this project is being undertaken in Romania, Slovakia, Serbia, and Macedonia (FYROM). One emerging question in the fieldwork regards the degree to which enclave city politics can be generalized, and not simply be understood as the personalitydependent work of local elites. Some of the dynamics of subnational authoritarianism (Gibson, 2005) are instructive here, as it could be that some enclaves present a variant of the mechanisms by which a local elite can "roll up" local political structures and keep oppositions out of power.

Once this project identifies general propositions on the political dynamics of enclaves, these propositions can then be examined against other settings. It would be especially useful to join up this research to that of others working in-depth in other enclave locations, to see how far potential generalizations might travel. It may be that enclaves in Africa exhibit vastly different dynamics than those in Eastern Europe, as indicated in research by Ishiyama on African enclave politics (2011). General mechanisms of outbidding, splintering, and polarization can be proposed inductively from specific locations, and the degree to which they travel to other locations might be verified by others doing local research there. Of course, this type of research is time-consuming and often requires local knowledge and language abilities. But with current technology, it is entirely feasible to create a network of local specialists who have interest in such questions. Parsimony is great, but finding the right explanations for political dynamics is better. 


\section{References}

Abbott, A. (2001). Transcending General Linear Reality. In A. Abbott (Ed.), Time Matters: On Theory and Method (pp. 37-63). Chicago: University of Chicago Press.

Almond, G. \& Genco, S. (1989). Clouds, Clocks, and the Study of Politics. In G. Almond (Ed.), A Discipline Divided. New York: Sage.

Barth, F. (1969). Introduction. In F. Barth (Ed.), Ethnic Groups and Boundaries: The Social Organization of Cultural Difference. Long Grove, Illinois: Waveland Press.

Beissinger, M. (2002). Nationalist Mobilization and the Collapse of the Soviet State. New York: Cambridge University Press.

Birnir, J. K. (2007). Ethnicity and Electoral Politics. New York: Cambridge University Press.

Blau, P. (1977). Inequality and Heterogeneity: a Primitive Theory of Social Structure. New York: The Free Press.

Brubaker, R. (2002). Ethnicity without Groups. Cambridge: Harvard University Press.

Brubaker, R., Feischmidt, M., Fox, J., \& Grancea, L. (2006). Nationalist Politics and Everyday Ethnicity in a Transylvanian Town. Princeton: Princeton University Press.

Chandra, K. (2006). What is Ethnic Identity and Why Does it Matter? Annual Review of Political Science 9, 397-424.

Connor, W, (1994). A Nation is a Nation, Is a State, Is an Ethnic Group, Is a.... In W. Connor, (Ed.), Ethnonationalism: The Quest for Understanding (pp. 90-117). Princeton: Princeton University Press.

Cunningham, K. (2009). Clan Politics and Regime Transition in Central Asia. New York: Cambridge University Press.

Emirbayer, M. (1997). Manifesto for a Relational Sociology. The American Journal of Sociology 103 (2), 281-317.

Fearon, J., \& Laitin, D. (1996). Explaining Interethnic Cooperation. American Political Science Review $90(4), 715-35$.

Fujii, L. A. (2008). The Power of Local Ties: Popular Participation in the Rwandan Genocide. Security Studies 17 (3), 568-97.

Gibson, E. (2005). Boundary Control: Subnational Authoritarianism in Democratic Countries. World Politics 58 (1), 101-32.

Giliano, E. (2011). Constructing Grievance: Ethnic Nationalism in Russia's Republics. Ithaca: Cornell University Press.

Granovetter, M. (1973). The Strength of Weak Ties. The American Journal of Sociology 78, 1360- 80.

Granovetter, M. (1985). Economic Action and Social Structure: The Problem of Embeddedness. The American Journal of Sociology 91(3), 481-510. 
Gross, J. (2003). Neighbors: The Destruction of the Jewish Community in Jedwabne, Poland. New York: Arrow / Random House.

Herrera, Y. (2004). Imagined Economies: The Sources of Russian Regionalism. New York: Cambridge University Press.

Horowtiz, D. (1985). Ethnic Groups in Conflict. Berkeley: The University of California Press.

Ishiyama, J. (2011). Explaining Ethnic Bloc Voting in Africa. Democratization 19 (4), 761-88.

Kaufman, S. J. (2001). Modern Hatreds: The Symbolic Politics of Ethnic War. Ithaca: Cornell University Press.

Kuran, T. (1991). Now Out of Never: The Element of Surprise in the East European Revolutions of 1989. World Politics 44, 7-48.

Massey, G. Hodson, R., \& Sekulić, D. (1999). Ethnic Enclaves and Intolerance: The Case of Yugoslavia. Social Forces 78 (2), 669-91.

McAdam, D., Tarrow, S., \& Tilly, C. (2001). Dynamics of Contention. New York: Cambridge University Press.

Pearlman, W. (2014). Violence, Nonviolence and the Palestinian National Movement. New York: Cambridge University Press.

Petersen, R. (2001). Resistance and Rebellion: Lessons from Eastern Europe. New York: Cambridge University Press.

Petersen, R. (2011). Western Intervention in the Balkans: The Strategic Use of Emotion in Conflict. New York: Cambridge University Press.

Pierson, P. (1993). When Effect becomes Cause: Policy Feedback and Political Change. World Politics 45 (4), 595-628.

Ron, J. (2000). Boundaries and Violence: Repertoires of State Action along the Bosnia/Yugoslavia Divide. Theory and Society 29, 609-49.

Roy, B. (1994). Some Trouble with Cows. Berkeley: The University of California Press.

Snyder, J. (2000). From Voting to Violence. New York: W.W. Norton.

Stroschein, S. (2007). Politics is Local: Ethnoreligious Dynamics under a Microscope. In S.

Stroschein (Ed.), Governance in Ethnically Mixed Cities. New York: Routledge. Previously a special issue of Ethnopolitics 6 (2), 173-85.

Stroschein, S. (2011). Demography in Ethnic Party Fragmentation: Hungarian Local Voting in Romania. Party Politics 17 (2), 189-204. 
Stroschein, S. (2012). Ethnic Struggle, Coexistence, and Democratization in Eastern Europe. New York: Cambridge University Press.

Stroschein, S. (2015). Book Symposium: Stroschein, Ethnic Struggle, Coexistence, and Democratization in Eastern Europe. Nationalities Papers 43 (4), 646-51.

Tilly, C. (2003). The Politics of Collective Violence. New York: Cambridge University Press.

Tilly, C. (2005). Identities, Boundaries \& Social Ties. Boulder: Paradigm Publishers.

Tilly, C. (2008). Contentious Performances. New York: Cambridge University Press. 